\title{
The Role of Religiosity Support in Generating Employee's Positive Work Behaviour
}

\section{Tri Wulida Afrianty*}

Business Administration Department, Faculty of Administrative Science, Universitas Brawijaya

\section{A R T I C L E I N F O}

Article history:

Received 01 December 2019

Received in revised form

31 December 2019

Accepted 15 January 2020

Available online 26

February 2020

Keywords:

Individual Religiosity,

Religiosity Support,

Organizational

Commitment, Social

Exchange Theory

\section{A B S T R A C. T}

The purpose of this research is to examine the impact of individual religiosity as well as religiosity support on employee's organizational commitment. This research is located in two Syariah Banking in Malang, East Java. A quantitative approach was undertaken in this research. The hypotheses were developed heavily based on Social Exchange Theory. The main finding of this research provides support to the theory, that is religiosity support (as a form of positive behaviour, managed by the organizations) has a significant impact in increasing employees' organizational commitment.

\footnotetext{
* Corresponding author.

E-mail addresses: twulidafia@ub.ac.id (Tri Wulida Afrianty)
} 


\section{Introduction}

Religiosity is an important value in the cognitive structure of an individual, which can affect the individual's behaviour, including work-related behaviours. As has been advanced by Azizah (2016), religiosity is an appreciation of one's religion-related symbols, beliefs, values and behaviours that are driven by spiritual power. The spiritual power here refers to the integration of religious knowledge, feeling and religious action of a person. Religiosity related to the implementation of religion in the real life of religious people. It is associated with attitude, behaviour, and the action of these religious people. According to Glock and Stark (1965) and Kucukcan (2000), there are five main dimensions of the individual religiosity as follows:

1.Intellectual (religious knowledge), that is constituted by the expectation that the religious person should have some knowledge about the basic doctrines of their faith and its religious scriptures. It is related to rules, traditions, rituals, and manner in conducting religion.

2.Ideological (religious belief), which gives recognition to the fact that all religions required the religious person should hold certain beliefs which adherents are expected to adhere to. The most important meaning of an individual who adheres to a religion is the willingness to abide the rules applied in religion doctrines.

3.Ritualistic (religious practice), this includes specific religious practices expected by adherents such as prayer, worship and fasting can be mentioned

4.Experiential (religious feeling), which refers to the achievement of direct knowledge of the ultimate reality or experience of religious emotions in the form of exaltation, fear, humility, joyfulness, peace, feel close to God and prayer granted by God.

5.Consequential (religious effect), this includes religious prescriptions which determine the attitudes of the adherents as a consequence of their religious belief. Glock argued that these are the core dimensions of religious commitment and shared by different religions of the world.

Specifically, in the workplace context, Darto et al. (2015) highlights that employees who possess a high level of religiosity perform a different working behaviour from those with low level of religiosity. People with high level of religiosity are most likely to demonstrate positive attitudes and behaviour in the workplace, such as being more responsible and committed to their jobs as well as to their organizations. Since religiosity can affect individual work-related behaviour, the concern about this issue has increased significantly among scholars and practitioners. However, empirical evidence about religiosity in the workplace context is still lacking (Afrianty, Issa, \& Burgess, 2016; Mahudin, Noor, Dzulkifli, \& Janon, 2016). Thus, the purpose of this research is to examine the impact of individual religiosity as well as religiosity support on employee commitment. Considering that research on the religiosity at the workplace context are still limited, examining the workplace religiosity in Indonesia is important. This is because Indonesia has been considered as being one of the most religious countries in the world where any religious related issues is very sensitive to Indonesian lives, including at the workplace. Moreover, the provision of workplace religiosity supports is governed by the Indonesia law and regulation (Afrianty, Issa, \& Burgess, 2016). Specifically, this research analyses the role of workplace religiosity support in enhancing the effect of individual religiosity on employees' commitment at two Syariah banking in Malang, East Java. The main research question that is examined in this research is "Does religiosity support mediate the relationship between individual religiosity and employees' affective commitment?".

\section{Methods}

A quantitative approach was undertaken for this research. The data for this study were gathered using structured questionnaires. The questionnaires distributed through a key person in the two organizations being investigated. The key person was obtained through the researchers' network. A total of 74 respondents from two Syariah Banks in Malang participated in this research. The data then analysed using SPSS version 25. To test the mediation effect, Baron and Kenny's steps are applied. According to Baron and Kenny (1986), a variable is considered as a mediator variable if the variable fulfilled the following conditions:

1. Independent variable must affect the mediator variable in the first equation;

2. Independent variable must be shown to affect the dependent variable in the second equation;

3. Mediator variable must affect the dependent variable in the third equation when the independent variable included into the model; and 
4. Independent variable on the dependent variable must be less in the third equation than in the second equation. A perfect mediation is obtained if the independent variable has no effect when the mediator variable is controlled.

\section{Result And Discussion}

Demographic information about the participants is shown in Table 1.

Table1. Respondents' Demographic Data

\begin{tabular}{llllllll}
\hline Gender & $\%$ & $\begin{array}{l}\text { Age } \\
\text { (year) }\end{array}$ & $\%$ & $\begin{array}{l}\text { Work Experiences } \\
\text { (year) }\end{array}$ & \% & Educational Level & $\%$ \\
\hline Male & 50.0 & $21-25$ & 25.67 & $1-5$ & 63.51 & Senior High & 2.67 \\
Female & 50.0 & $26-30$ & 47.30 & $6-10$ & 28.38 & Diploma & 9.33 \\
& & $31-35$ & 16.22 & $11-15$ & 5.41 & Bachelor's degree & 88.00 \\
& & $36-40$ & 5.41 & $16-20$ & 2.70 & & \\
\hline
\end{tabular}

\section{Hypotheses Testing}

In order to test the hypotheses, a hierarchical regression analysis was carried out applying the Baron and Kenny's approach for mediating testing. The results of the hypotheses testing are shown in Table 2.

Table 2. Hypotheses Testing Result

\begin{tabular}{llll}
\hline Predictors & $\begin{array}{l}\text { Model 1 } \\
\text { Religiosity Support }\end{array}$ & $\begin{array}{l}\text { Model 2 } \\
\text { Organizational } \\
\text { Commitment }\end{array}$ & $\begin{array}{l}\text { Model 3 } \\
\text { Organizational } \\
\text { Commitment }\end{array}$ \\
& $\boldsymbol{\beta}$ & $\boldsymbol{\beta}$ & $\boldsymbol{\beta}$ \\
\hline Individual & $\mathbf{0 . 5 3 5 *}$ & $\mathbf{0 . 3 5 7 ^ { * }}$ & $\mathbf{0 . 1 3 8}$ \\
Religiosity & & & 0.116 \\
$\mathrm{R}^{2}$ & 0.277 & 0.116 & $\mathbf{0 . 9 2 6 ^ { * }}$ \\
Religiosity Support & & & 0.732 \\
$\mathrm{R}^{2}$ & & & \\
\hline
\end{tabular}

Notes: ${ }^{*} \mathrm{p}<0.005$

As can be seen in table 2 , individual religiosity has a positive significant impact on religiosity support $(\beta=0.535, p<0.005)$. Thus, hypothesis 1 of this research is supported. Related to the second hypothesis of this research, it can be seen that individual religiosity significantly affects organizational commitment $(\beta=0.357, p<0.005)$ which means that hypothesis 2 of this research is supported. Regarding the third hypothesis, as can be seen on table 2, religiosity support has a significant effect on organizational commitment $(\beta=0.926 ; p<0.005)$. Considering the Baron and Kenny's approach, all the conditions for a mediator variable have been met and it can be seen that the impact of religiosity support on organizational commitment become insignificant when the mediator variable is controlled (see model 3). Thus, hypothesis 4 of this research is supported.

\section{Conclussion}

The findings of this research provide support for the application of social exchange theory in the field of human resource management, that is employees will develop high quality relationships with the organization based on the positive experiences they have gained from their organizations. In this research, it is found that the religiosity supports (that are valuable or in line with the employees' main belief) given by the organizations to their employees were able to generate organizational commitment among the employees. This implies that it is beneficial for organizations to keep managing religiosity supports for their employees effectively as one of the strategies to improve employees' work-related behaviour. 


\section{Reference}

Afrianty, T. W. (2013). Work Life Balance Policies in the Indonesian Context. (November), 267. Retrieved from $\quad$ http://espace.library.curtin.edu.au/R?func=dbin-jump-full\&local base=gen01era02\&object id $=199554$

Afrianty, T.W., Issa, T., \& Burgess, J. (2016). Work-based religiosity support in Indonesia. In S Gröschl, R Bendl (eds) Managing religious diversity in the workplace: Examples from around the world. Ashgate Publishing, Ltd

Azizah, Siti Nur. (2016). Religiosity Dimensions and the Effect on Organizational Citizenship Behavior Islamic Perspective. The International Conference of Management Sciences (ICoMS). 236- 247.

Baron, R. M., \& Kenny, D. A. (1986). The moderator-mediator variable distinction in social psychological research: conceptual, strategic, and statistical consideration. Journal of personality and social psychology, 51(61) pp. 1173-1182

Blau, P. (1964). Exchange and power in social life. New York: Wiley

Cohen, A. (2007). Commitment before and after: An evaluation and reconceptualization of organizational commitment. Human Resource Management Review, 17, 336-354.

Cropanzano, R., \& Mitchell, M. S. (2005). Social Exchange Theory: An Interdisciplinary Review. Journal of Management, 31(6), pp. 874-900.

Darto, Mariman., Setyadi, Djoko., Riadi, Sukisno S., \& Hariyadi, Sugeng. (2015). The Effect of Transformational Leadership, Religiosity, Job Satisfaction, and Organizational Culture on Organizational Citizenship Behavior and Employee Performance in The Regional Offices of National Institute of Public Administration, Indonesia. European Journal of Business and Management. 7(23): 205- 219. ISSN 2222- 2839

Glock, Charles Y. and Rodney Stark. 1965. Religion and Society in Tension. Chicago: Rand McNally.

Gouldner, A. W. (1960). The Norm of Reciprocity: A Preliminary Statement. American Sociological Review, 25(2), 161-178.

Kucukcan, Talip. (2000).Can Religiosity be Measured: Dimensions of Religious Commitment. Theories Revisited. 9(9): 1-5.

Mahudin, N., Noor, N., Dzulkifli, M., \& Janon, N. (2016). Religiosity among Muslims: A Scale Development and Validation Study. Hubs-Asia, 20(2), 109. https://doi.org/10.7454/mssh.v20i2.480

Meyer, J. P., \& Allen, N. J. (1984). Testing the "Side-Bet Theory" of organizational commitment: Some methodological considerations. Journal of Applied Psychology,69(3), 372-378.

Meyer, J. P., \& Allen, N. J. (1991). A three-component conceptualization of organizational commitment. Human Resource Management Review, 1(1), 61-89.

Meyer, J. P., Allen, N. J., \& Smith, C. A. (1993). Commitment to organizations and occupations: Extension and test of a three-component conceptualization. Journal of Applied Psychology, 78(4), 538-551. 